\title{
Economía de mercado, globalización y migración: retos y rostros de las personas vulneradas globales. Un análisis desde Karl Polanyi
}

\author{
Jefferson Frenel Junior Pierrelus Francois*
}

\section{$\boldsymbol{R}$}

esumen

Este ensayo pretende demostrar cómo el mercado autorregulado que pregona el neoliberalismo es una falacia y que tiende tarde que temprano a acabar o destruir las propias condiciones sociales, ambientales y culturales que aseguran la vida en el planeta. Basado en una globalización financierista, en la privatización y en la liberalización de mercado, ese modelo se ha convertido en la mayor fábrica de empobrecidos, logrando cooptar y subordinar a los Estados a sus designios a través de las grandes empresas transnacionales e instituciones económicas internacionales. La neo-esclavitud, la miseria, la precariedad y la violencia se han instalado como un modo de ser y de vivir, aunadas a la emigración, debido a esa explotación, extracción de recursos naturales a ultranza que lleva a cabo ese modelo económico imperante. Hay voces, manifestaciones, como la de Karl Polanyi, que quieren poner un freno a ese molino satánico, llamado neoliberalismo.

Palabras clave: Economía de mercado, globalización, violencia y migración

\section{Market Economy, Globalization and migration: challenges and faces of global vulnerable peoples: An analysis from Karl Polanyi}

\section{Abstract}

This essay aims to demonstrate how the self-regulated market that neoliberalism proclaims is a fallacy and that tends sooner rather than later to end or destroy the very social, environmental and cultural conditions that ensure life on the planet. Based on financial globalization, privatization and market liberalization, this model has become the largest factory of the impoverished, managing to co-opt and subordinate the States to their designs through large transnational corporations and international economic institutions. Neo-slavery, misery, precariousness and violence have been installed as a way of being and living, coupled with emigration, due to this exploitation, extraction of natural resources at all costs that this prevailing economic model carries out. There are voices, demonstrations, like Karl Polanyi, that want to put a stop to that satanic mill, called neoliberalism.

Keywords: Market economy, globalization, violence and migration

* Dr. en Ciencias Sociales por la Universidad de Guadalajara. Especialista en Migración Internacional. Profesor en el ITE-

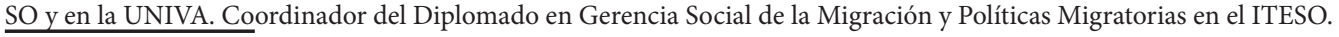


A través del profundo análisis de la sociedad occidental realizado en su inagotable y clásica obra La gran transformación, Karl Polanyi explica cómo el crecimiento del mercado autorregulado y de las relaciones económicas capitalistas destruía (como hoy) sus propias condiciones sociales y ambientales. Su obra sigue más que nunca vigente en un mundo manejado por una globalización financierista maquillada de modernización económica y de desarrollo; modernización que, dicho sea de paso, no es sino un eufemismo para adaptarse a las reglas del nuevo orden global, de acuerdo con Zizek (Zizek, 2016). Polanyi insiste y nos invita: “.. a analizar el proceso a través del cual el capital utiliza formas autodestructivas de mercantilización, proletarización de la naturaleza humana, enajenación de la fuerza de trabajo y apropiación del trabajo" (O'Connor, 2001:192).

En efecto, con la consolidación de este sistema capitalista se dio la mercantilización y capitalización de la naturaleza, incluida la humana. En este sentido el mismo autor afirma: "La tierra y el trabajo se volvieron mercancías ficticias con precios ficticios; renta y salario se convirtieron en formas particulares de capital" (O'Connor, 2001:42).

En este mismo orden de ideas, hemos sido testigo de la metamorfosis del capitalismo liberal en capitalismo neoliberal. Esa versión del capitalismo remonta a las décadas de los treinta y cuarenta del siglo pasado. Su doctrina se va a convertir en política de Estado a mediados de los años setenta en Chile con Pinochet y a principios de los años ochenta en Inglaterra y Estados Unidos con Margaret Thatcher y Ronald Reagan, respectivamente. Sus pensadores importantes son Von Hayek, Ludwig von Mises, Milton Friedman, entre otros.

Con la privatización y liberalización del mercado como dogma, el movimiento neoliberal logró su cometido, a saber, apropiarse del aparato estatal para llevar a cabo una nueva ronda de "cercamiento de los bienes comunales, públicos", como se dio en Inglaterra durante la consolidación del capitalismo. Los bienes públicos fueron lanzados al mercado para que el capital sobre-acumulado pudiera invertir en ellos, reformarlos y especular con ellos. Empero, cuando algo les sale mal, disponen del Estado para rescatarlos.

El neoliberalismo, y la privatización que le es inherente, es una máquina de fabricación de empobrecidos, de dislocación y anomia social en lenguaje durkheimiano, y también facilita para unos pocos la acumulación a través del despojo: una pequeña élite cada vez más rica a costa de los desheredados, de las víctimas de dichas políticas económicas. Éstas tienen que ver con la desregulación de los mercados finan- cieros y su liberalización. En este sentido Boltansk y Chiapello avanzan lo siguiente: "La desintermediación y la creación de nuevos productos financieros han multiplicado las posibilidades de obtener beneficios puramente especulativos mediante los cuales se incrementa el capital en detrimento de la inversión en actividades productivas, lo cual genera desempleo, empobrecimiento y violencia" (Boltansk, Chiapello, 2002:20).

Como podemos darnos cuenta, a lo largo de las últimas tres décadas, la reestructuración del capitalismo neoliberal reflejada en los mercados financieros y en los movimientos de fusión-adquisición de las multinacionales se ve acompañada de políticas gubernamentales favorables al gran capital en materia fiscal, social, salarial, ambiental, laboral, entre otras. Asistimos al nacimiento de un nuevo modelo capitalista depredador del medio ambiente; de un capitalismo neo esclavista, sin trabajo, sin impuestos o exención de los mismos para las grandes empresas y corporaciones multinacionales. Un capitalismo que, a través de éstas, chantajea, amedrenta y somete a los Estados-nación y dicta las políticas de éstos; además, con derecho a demandarlos si sus intereses se ven amenazados.

La pregunta que nos formulamos en este trabajo es: ¿cómo establecer nuevas reglas y bases políticas, y sociales para detener y reorientar este capitalismo neoliberal con todas las consecuencias nefastas que ha exhibido a nivel global? Una tentativa de respuesta sería que el Estado vuelve a asumir su papel como regulador, promotor de desarrollo y defensor de la dignidad humana ante ese molino satánico que es ese modelo económico, y así disminuir y evitar la emigración en condiciones infrahumanas y de negación de derechos a las personas empobrecidas y de manera particular a las migrantes.

Con todo lo anterior mencionado, me propongo en este ensayo reflexionar en torno a la crisis multidimensional y global actual que suscita el modelo capitalista neoliberal a partir del texto de Polanyi, La Gran Transformación, y desde autores como Beck, O'Connor, Mittelman, Harvey, entre otros.

Este trabajo consta de tres partes. En la primera, me enfocaré a analizar la realidad y las falacias del capitalismo neoliberal desde Polanyi. En la segunda parte, abordaré la problemática de la globalización neoliberal y sus consecuencias en la vida social. Por último, analizaré uno de los efectos de ésta que es la emigración. Y terminaré con una conclusión. Pretendo en este texto reflexionar sobre las relaciones entre el sistema capitalista neoliberal, la globalización y la migración y, de manera particular, sus consecuencias en nuestra región, América Latina. El objetivo plan- 
teado es ayudar a una mayor comprensión de la realidad migratoria actual provocada en gran medida por este modelo económico neoliberal vigente.

\section{Un acercamiento a esta etapa neoliberal capitalis- ta desde el enfoque de Polanyi}

El neoliberalismo se parece mucho al leviatán de Hobbes, el cual, para sobrevivir y vivir, requiere de un número infinito de cuerpos humanos, de mucho flujo de sangre humana a su entera disposición. En efecto, un caso que explica esta idea es el mecanismo utilizado para bajar el salario en el mundo laboral y más en los países tercermundistas. Eso se lleva a cabo a través de infundir miedo a la población de caer en una inflación económica, utilizando mecanismos encaminados a cooptar, controlar y eliminar los sindicatos y persuadir a los trabajadores a aceptar esas nuevas condiciones laborales y salariales impuestas, so pena de verse orillado a quedarse sin sustento para sí mismos y sus familiares.

Por lo tanto, aquellas personas trabajadoras han tenido muy poco que decir en la determinación de su propio destino, de su fuerza de trabajo. Esa nulificación de la capacidad de agencia del trabajador lleva a una cosificación de su persona. Sacarla fuera de la ley y del ámbito de derechos la reduce a ser un esclavo sin el nombre; es lo que se conoce como la neo-esclavitud. En efecto, muchos empleadores buscan y prefieren trabajar por lo general con obreros y/o migrantes vulnerados por la miseria, el hambre y por la violencia. Los primeros hacen creer a éstos que el mercado es el que determina el precio de sus trabajos. Sin embargo, como lo ha dicho Polanyi, nunca han existido los mercados laborales o de bienes en verdad libres (Polanyi, 2003; Stiglitz, 2011).

Esa neo-esclavitud aceptada por miedo a quedarse sin empleo, se ve acompañada por una progresiva eliminación o reducción de las protecciones y subsidios sociales, impuesta por las instituciones financieras y económicas internacionales controladas por las grandes potencias.

Las presiones que ejercen esos países desarrollados y sus representantes desde esa ideología neoliberal han tenido y tienen consecuencias desastrosas en aquellos países donde se aplicó la receta neoliberal al pie de la letra, como fue el caso primero de Chile, de Argentina y desde luego México, con la subsecuente devaluación de 1994 y el rescate bancario. A todas luces se sabía o se tenía contemplado que la manera de llevar a cabo esta nueva liberalización acarrearía enormes riesgos a esos países, y que éstos perjudicarían a casi todos los sectores sociales y sobre todo a los empobrecidos.
En efecto, en los países pobres y empobrecidos, con altos índices de desempleo, el neoliberalismo, y el libre comercio que pregona, han provocado la cancelación de nuevas plazas de empleo, el aumento de los precios de productos de primera necesidad, el aumento de la inflación, de la deuda pública e internacional. Los efectos de dichas políticas saltan a la vista, a lo largo de este período a través del aumento significativo de la miseria, del desempleo-precariedad, de la violencia, del deterioro ambiental y de la migración.

De hecho, uno de los defectos de la economía autorregulada o de libre mercado ${ }^{\text {ii }}$ es la relación que guarda con la sociedad, en este caso de subordinación, ya que, en este modelo, la sociedad o las personas que la conforman son las que están al servicio de aquélla. Esas consecuencias arriba aludidas han tenido efectos desastrosos en la economía, en la cohesión social y en la salud psicosocial de las personas.

En una palabra, dichas aplicaciones en América Latina erosionaron las relaciones sociales, destruyeron el capital social y el campo; generaron y desataron la migración y la criminalidad en prácticamente toda la región. La eliminación de los subsidios, la apertura comercial desenfrenada, la mercantilización de los derechos sociales, el abandono del campo y la precariedad laboral terminaron por hundir a los países en la pobreza, por acelerar una escalada de migración tanto interna como externa y una inestabilidad política y social que hasta hoy no cesa. Casi todas las Constituciones del Continente fueron modificadas, reformadas para dar inicio al saqueo legal. En México, por ejemplo, se modificó el artículo 27 constitucional, en lo referente al campo mexicano, entre otros, para liberalizarlo y desmantelar el ejido mexicano.

En este sentido, el empobrecimiento y la migración que se derivan pueden explicarse -además de otros factores- también desde los condicionamientos macroeconómicos impuestos por el Fondo Monetario Internacional (FMI), el Banco Mundial (BM) y el Banco Internacional de Desarrollo (BID) a los países de la región, los cuales terminaron por mermar la capacidad productiva de los mismos.

Así, uno de los recursos que se dispone, como lo menciona Saxe-Fernández, es la emigración para poder sobrevivir ya que los subsidios fueron retirados a los campesinos para beneficiar y facilitar la entrada a las grandes corporaciones extranjeras (Saxe-Fernández, 2014).

Parece que existe una correlación perversa entre la aplicación de los Programas de Ajuste Estructural (PAE) y el aumento sin precedente del empobrecimiento y de la migración en América Latina y el Caribe. Condenados y/u obligados a exportar ma- 
terias primas y minerales, cuando muchos países de la región tienen altas potencialidades para desarrollar y emprender un proceso industrializador propio para abatir la pobreza y la desigualdad, como lo ilustra el caso de Bolivia, con Evo Morales en el poder y que fue derrocado por los conservadores y militares a finales del 2019. Dichos países se ven, en cambio, entrampados en conflictos sociales y políticos, algunos de éstos son orquestados desde el imperio para desestabilizar los gobiernos que quieren tomar distancia de ese modelo neoliberal; otros son consecuencia de la desigualdad abismal e insultante despojo y miseria que vive la mayoría de la población de dichos países de la región.

Desregularización, apertura comercial, privatización de las industrias nacionales e invasión extranjera directa (IED), como lo nombra Saxe-Fernández (2014:26), en lugar de Inversión Extranjera Directa, esta trilogía sigue causando enormes estragos en las respectivas sociedades de esa región y del mundo.

Por si fuera poco, el derecho a manifestar el descontento social se reprime con las fuerzas que resguardan el desorden - económico y social. Los casos actuales de Chile, Haití, Ecuador, Bolivia, Francia y Colombia durante los últimos cuatro meses del 2019 y principios del 2020 son una muestra del gran descontento generalizado que genera ese modelo económico por el despojo, empobrecimiento, precariedad y negación de derechos que aplica como forma de vida a nivel planetario, los cuales favorecen a una pequeña élite detentora de la inmensa riqueza mundial. Ese modelo económico rapaz y represor necesita de la fuerza para reprimir a los descontentos. Dichas represiones revelan o hacen pensar a su vez en el lazo que tejen los tres poderes, a saber, el poder político, económico y militar, para desmantelar el Estado de bienestar, a través de la privatización, apropiación de los bienes y recursos naturales de los respectivos países; son acciones políticas y económicas encaminadas a provocar la inestabilidad social, la emigración y la violencia sin precedente que se vive en la región.

Una de las caras del neoliberalismo es lo que se dio a conocer bajo el nombre de Consenso de Washington firmado a principios de los 90's. En efecto, este supuesto consenso se asemeja más a una imposición de las Cúpulas del poder geopolítico y económico, donde lo que priva es el monopolio y la especulación financiera. Provocó el quiebre de muchas pequeñas y medianas empresas y la venta de empresas o industrias estatales ordenados y orquestados por esos poderes antes aludidos. Esos casos son determinantes claves de la situación de América Latina.
En este sentido, la globalización viene siendo los rieles sobre los cuales corre el tren del sistema económico neoliberal financierista y a muchos no les queda otra opción que intentar subir en él cuando éste se dirige a los países e instituciones que han provocado y legitimado este despojo, por ejemplo, Estados Unidos de América. A ésos que huyen del hambre al subirse a ese tren les llaman criminales, o como diría Baumann, vagabundos, y a la élite nacional que se ha beneficiado de esas reformas estructurales, les llaman turistas o migración dorada (Saxe-Fernández, 2014) porque tienen residencia, casas en esos países.

Asistimos, pues, a una violencia política orquestada desde las altas esferas e instituciones de los tres poderes: político, económico y militar a nivel nacional, regional, continental y mundial a través de la imposición de ese modelo económico; y también a una política de la violencia; ambas se necesitan para lograr el despojo de los países y así aumentar el capital económico, político- militar de las grandes potencias y sus empresas transnacionales.

Como se ha de esperar, las políticas económicas vigentes terminaron por romper de por sí frágil el tejido social latinoamericano, y muchas veces contaron con la complicidad, corrupción y el silencio del Estado. La economía de mercado autorregulado no tiene los recursos, ni puede, -ni es su intención- reconstruir lo que ha destruido; tales como: el desempleo, los daños al medio ambiente, el empobrecimiento de la población, la violencia, entre otros. No está en su ADN erradicar la pobreza, ya que sus remedios tienden a empeorar y aumentar las causas de la misma y debilitan aún más las instituciones del Estado y la capacidad de agencia de la sociedad. Su búsqueda de acumulación destruye el modus vivendi de las comunidades; los mecanismos antiguos de contención de la pobreza; rompe las antiguas redes de seguridad y de solidaridad que se tejían.

Por otra parte, el Consenso de Washington, versión moderna de la ortodoxia liberal, es un claro ejemplo de ello: debilitar todas las redes de seguridad social, alimentaria, cultural que encuentre en su paso, en nombre de la democracia liberal. De hecho, el neoliberalismo, como proyecto político que subordina al Estado, se puede explicar a través de estos puntos nodales desde los cuales se aplica el "Consenso de Washington" (Leonardo Girondella Mora, citado por Álvarez Acosta, 2010:29): 
1. Disciplina presupuestaria de los gobiernos

2. Reorientar el gasto gubernamental a áreas de educación y salud

3. Reforma fiscal o tributaria, con bases amplias de contribuyentes e impuestos moderados

4. Desregulación financiera y tasas de interés libre de acuerdo al mercado

5. Tipo de cambio competitivo, regido por el mercado

6. Comercio libre entre naciones

7. Apertura a inversiones extranjeras directas

8. Seguridad de los derechos de propiedad

9. Privatización de empresas públicas

10. Desregulación de los mercados

Lo que buscan los teóricos y voceros neoliberales es apropiarse y apoderarse de la economía de los países. Para ello, necesitan del apoyo y complicidad del Estado. Si esto se logra, el país se verá despojado de sus riquezas tangibles e intangibles. De esa manera, no sería exagerado comparar ese sistema imperante a un semáforo descompuesto, donde pasan los grandes camiones, tráileres (países industrializados) y donde reina el caos dentro de un orden ficticio impuesto como norma; los transeúntes, como los que andan en bicicleta (países subdesarrollados) corren serios riesgos de ser atropellados, heridos de muerte al querer recorrer y atravesar las avenidas de la competencia y del desarrollo económicos.

Interpretando a Polanyi, el retiro del Estado, como regulador de este semáforo, ha generado un capitalismo mafioso y corrupto, y un sistema político mafioso y corrupto, muchos casos abundan en AL y en el mundo. Esas prácticas mafiosas, corruptas tienden a propalarse y erigirse en norma en sociedades donde la economía se ha convertido en un fin en sí misma y no como algo que forma parte de y está al servicio de ésta.

Este capitalismo periférico mafioso y corrupto busca cumplir más con las exigencias de la comunidad financiera, la cual enfatiza el recorte en los campos sociales y el control de la inflación, aunque provoquen más desempleo y pobreza. Con estas acciones comerciales, políticas y financieras que favorecen a las grandes transnacionales y debilitan el mercado interno dictan la sentencia de muerte de los empobrecidos.

Neoliberalismo significa para la gran mayoría de la población latinoamericana negación de derechos humanos, sociales, culturales, económicos y ambientales. La negación de derechos y la economía autorregulada parecen ir de la mano, aunque, como Polanyi ha demostrado, el mercado nunca ha sido libre, ni los precios se establecen de manera libre. Los grandes centros de poder económico y político lo mueven a sus conveniencias. Por lo tanto, este mito del mercado autorregulado tanto en su versión del laissez-faire, laissez-passer, como en su fase maquillada de Consenso de Washington, sigue causando los mismos daños en nombre de la misma ideología: la libertad en una sociedad compleja.

Empero los pobres no han podido liberarse del hambre, de la miseria, ni de la exclusión social, ni qué decir de la libertad de expresión, de culto, etc. De hecho, Como dice Sen: “... para ellos enfrentan más que nadie un mayor sentimiento de inseguridad. Para ellos, hay menos libertad ante el hambre ante la explotación, el racismo, menor libertad ante la muerte" (1995:74). En ese caso, la única alternativa es enrolarse en el crimen organizado, emigrar, como sucede con la caravana de los migrantes centroamericanos que se dirigen a Estados Unidos de América, atravesando México durante los últimos cuatro meses del 2018 hasta la fecha.

Si la economía se ha convertido en un fin en sí es porque se ha desarraigado de la sociedad en su conjunto, nos dice Polanyi. El término "arraigo" indica que la economía ha de estar al servicio de la sociedad y que ésta tiene dimensiones políticas, sociales, culturales, religiosas, y ha de considerarse como una dimensión entre aquéllas y no la única ni la principal como pretenden los apologistas neoliberales.

En este caso, el gran logro de los teóricos de libre mercado o mercado autorregulado, es hacer que la sociedad se subordine a la lógica mercantil a través del consumismo, el individualismo y la autopercepción clasista. También lograron transformar los seres humanos y el ambiente natural en mercancías, lo que asegura su manipulación, devaluación, explotación y, por qué no, hasta su desechabilidad y aniquilación.

Mercancía, para Polanyi, es algo que se produce para venderse en un mercado. Así, la tierra, el trabajo, las personas y el dinero son mercancías ficticias porque no se produjeron originalmente para venderse en un mercado. Para lograrlo, es imperante (si el caso lo amerita) recurrir al uso de la fuerza y disfrazar de legalidad el saqueo.

Esa treta se transformó en políticas de miedo y de control sobre la sociedad. Control de unos cuantos, y que son económicamente fuertes. Cuando aquéllas se dirigen hacia el desarraigo de la economía de la sociedad, hacia la autorregulación de los mercados, a la competencia, la sociedad se ve obligada a absorber los costos mayores, como pobreza, violencia, desempleo, emigración, etc. (Block, 201).

Por otra parte, la desencrustración ${ }^{\mathrm{iii}}$ o desarraigo del mercado provoca situaciones como la reportada por Oxfam México (2015), donde más de veinte millones de personas viven en la pobreza extrema y teniendo al hombre más rico del mundo. Esa es- 
dalosa desigualdad y la cooptación del Estado por parte de las élites económicas acarrean graves consecuencias en todas las dimensiones de la vida nacional.

En este sentido, no es de extrañar el debilitamiento del mercado interno y la disminución de los pequeños negocios, debido a la reducción y/o eliminación de los derechos sociales. Lo que sí aumentó, aunado con la violencia y la desigualdad, es la cantidad de los millonarios en México principalmente. En el caso mexicano, creció en un 32\% entre 2007 y 2012 (Oxfam, 2015).

Como prueba de esa enorme desigualdad, Esquivel afirma lo siguiente: “...Para el año 2014, los cuatro principales multimillonarios mexicanos podrían haber contratado hasta 3 millones de trabajadores mexicanos pagándoles el equivalente a un salario mínimo, sin perder un solo peso de su riqueza" (Oxfam, 2015: 8). El mismo autor avanza lo siguiente: Las implicaciones de lo anterior no son sólo de índole social. Carlos Slim en la telefonía, Germán Larrea y Alberto Bailleres en la industria minera y Ricardo Salinas Pliego en TV Azteca, Iusacell y Banco Azteca. Los cuatro han hecho sus fortunas a partir de sectores privados, concesionados y/o regulados por el sector público. Estas élites han capturado al Estado mexicano, sea por falta de regulación o por un exceso de privilegios fiscales (Oxfam, 2015: 8).

Estas políticas arriba mencionadas generan severas reacciones, descontentos, violencia y serios problemas en el orden social; reflejan el contubernio de los empresarios con los políticos que han de vigilar por el bienestar social.

Por otra parte, como hemos mencionado arriba, este modelo neoliberal requiere de un disfraz democrático para disimular y esconder el autoritarismo tanto financiero como social que ejerce sobre los respectivos países. Las grandes transnacionales e instituciones financieras que dictan las políticas de los países no fueron elegidas por los ciudadanos de esos países. Dicho autoritarismo evidencia, como bien lo apunta García Canclini (2001), la reducción, la merma de poder cada vez mayor por parte de los políticos y convierte a éstos en simples administradores, gerentes de intereses transnacionales.

La gran capacidad previsora y visionaria de Polanyi advertía ya del gran riesgo que se corre al adoptar el mercado autorregulado como forma de llevar la vida socioeconómica del mundo. Afirma Polanyi (2011) que el mercado autorregulado implicaba una utopía total; no podría existir durante largo tiempo sin aniquilar la sustancia humana y natural de la sociedad; habría destruido físicamente al hombre y transformado su ambiente en un desierto.
El mismo papel jugado por la haute finance a finales del siglo XIX y principio del siglo XX en la organización político-económica del mundo, revela Polanyi, el neoliberalismo como sistema económico y social desempeña ese mismo rol que consiste precisamente en una reorganización, reconexión y subordinación de las instituciones políticas, jurídicas y sociales del mundo en beneficio de las élites internacionales y nacionales, donde la globalización-homogeneización funciona como puentes, túneles para agilizar y facilitar el saqueo, acumulación de riquezas, abusos y excesos por parte de los bancos y empresas transnacionales, como lo había señalado Raghuram Rajan (2011). Su motivación era y es la ganancia máxima a toda costa.

$\mathrm{Al}$ igual que en la época de los Tudor en la Inglaterra del Siglo XVI los advenedizos llegan al poder e imponen su espíritu de acumulación, de avaricia y de alta corrupción, una política muy severa para los pobres, aunada a la sed de lujo y de placer de aquéllos. Paris ilustra esta situación de esa manera:

Los nuevos burgueses poseían todo en este ambiente de sobornos, privilegios consentidos bajo recomendaciones, plagado de intermediarios; los cargos se venden y se compran; las malversaciones se convierten en el denominador común de esta sociedad, provocando así la constitución de clanes que buscan controlar las palancas del Estado. Es la época del favoritismo, de monopolios y de la corrupción entre la casa royal y los nuevos burgueses, mientras que el resto de la sociedad vive en la miseria y en el olvido (Paris, 1954:14-16).

En una palabra, era presionar al rey para conseguir derechos de monopolio (Rodrik, 2011:27). El modelo neoliberal actual parece compartir muchos rasgos del capitalismo mercantil del siglo arriba mencionado.

En otro orden de ideas, conviene mencionar que, debido al desarraigo de la economía de la sociedad, hay una tendencia hacia el economicismo (Bleck, 1998), donde las demás dimensiones, como la política, la cultura, el enfoque de género, lo social se ven relegadas a último término. Hoy, nos damos cuenta de que las políticas públicas suelen alejarse del sentir y necesidad de las personas; son exclusivas para expertos y no para los ciudadanos y se llevan a cabo dentro de un anonimato, un ente difuso, característica de la dinámica de la globalización política (Mittelman, 2002). Los intereses que guían aquellas políticas son los de la división internacional del trabajo, de la extracción de los recursos que realizan las grandes empresas transnacionales, de las grandes instituciones financieras internacionales flanqueadas con el apoyo de los medios de desinformación, y con las fuerzas del orden. 
El mercado, como sostiene Mittelman (2002), sigue siendo el motor de la globalización y también de la política internacional como nacional.

Los trabajos se hacen cada vez más para otros, ni siquiera para patrones o jefes identificables, sino para empresas transnacionales, fantasmáticas sociedades anónimas que dictan desde lugares poco conocidos reglas indiscutibles e inapelables y cada vez está más limitado lo que los sindicatos pueden negociar, y a eso las empresas sin rosto, con marca pero sin nombre, llaman "flexibilizar el trabajo (2002:26-27).

Ese capitalismo neoliberal globalizado desincrustado de la sociedad opera una transformación total en todos los ámbitos de la vida y en todos los países. Los denominadores comunes de esa transformación son principalmente una mayor cantidad de personas vulneradas en sus derechos humanos, sociales, culturales, ambientales; pérdida de soberanía efectiva en el campo político.

En lo cultural se da un rechazo a la diferencia y al diferente, una homogeneización de la cultura global dominante y una mercantilización de los aspectos simbólicos, patrimoniales de la misma; un rechazo de los pobres, un auge de la discriminación, lo cual se traduce en rechazo, exclusión y negación de derechos.

En lo social, asistimos a una mayor precariedad laboral, desempleo, violencia, achicamiento de la clase media y mayor acumulación de riqueza por parte de los ricos. La híper-competitividad se combina en un mismo país con el híper abandono, la híper exclusión y segregación. El Estado donde se aplica el sistema económico neoliberal, si bien no abandona la política social, tiende a reducir los derechos sociales o en palabra de Montalvo (2013) a desentenderse de la responsabilidad por el bienestar social general o delegar esa responsabilidad a otros actores sociales y políticos.

En este sentido, la democracia tiende a perder su razón de ser y se convierte en un simple mecanismo a través del cual se elige a los futuros gerentes o cortesanos de la corte (imperio) neoliberal transnacional.

En efecto, de acuerdo con Montalvo, la democracia para los neoliberales no tiene nada que ver con las condiciones en las que viven los votantes. Hemos pasado del Estado dictador autoritario al Estado neoliberal dictatorial, autoritario, que promueve, como afirma este autor: “...la desaparición de muchos derechos sociales: salud, pensiones, subsidio al campo, a la producción, al consumo, gasolina, educación, etc." (2013:22).
Por otra parte, este auge de la teoría neoliberal y su política de privatizaciones se aprecia en esta gran transformación que sufre la economía mundial con la financiarización del mercado y de la economía en general a través de ataques severos de devaluación y acumulación por privatización; todo eso se lleva a cabo con la complicidad y participación del Estado, al decir de Harvey, que es: "un agente destacado en la acumulación por desposesión por parte de las grandes transnacionales" (2006:34).

La globalización neoliberal crea sus descontentos y sus parias que buscan de una forma u otra resistir a sus embates. Con Polanyi, nos percatamos de que la resistencia y las nefastas consecuencias de la globalización neoliberal y el mal manejo de la misma pueden llevarnos a un punto sin retorno, a un caos, a guerras, como se está dando en la actualidad.

En efecto, este inagotable doble movimiento nos ayuda a entender con nitidez cómo una expansión del mercado sin precedentes implica una dislocación, desarreglo social masivo y una reacción política por parte de los afectados en forma de demandas sociales, exigiendo al Estado poner un freno a la expansión del mercado, a las privatizaciones, que desencadenan efectos perjudiciales para las sociedades: lo podemos apreciar desde el movimiento Ocupa Wall Street hasta los chalecos amarillos en París, Francia, en el mes de diciembre de 2018.

No cabe duda de que, al igual que la economía global de los años 30 del siglo pasado, la globalización neoliberal actual se está acercando a una coyuntura en donde las estructuras económicas neoliberales que fomentan el mercado autorregulado generan desarreglos, desarraigos políticos, sociales y económicos en gran escala. ¿Sabremos manejar tantos desarraigos, alcanzaremos a vislumbrar las consecuencias de los mismos?

\section{La globalización neoliberal y las consecuencias de la expansión del mercado autorregulado}

Nos revela Polanyi que el origen del cataclismo arriba mencionado se encontraba en el esfuerzo utópico del liberalismo económico (hoy neoliberalismo) por establecer un sistema de mercado autorregulado. Esto implicaba que la balanza de poder, el patrón oro y el Estado liberal estaban forjados por una matriz común: el mercado autorregulado (Polanyi, 2011).

La búsqueda exclusiva de acumulación económica a toda costa genera consecuencias aciagas en las relaciones sociales. De hecho, como afirma Polanyi "la esencia del progreso puramente [...] se da al precio de la dislocación social. Habría que recordar que los cercamientos fueron una revolución de los ri- 
cos contra los pobres, perturbaron el orden social, derogando antiguas leyes y costumbres, por medios violentos, presiones e intimidación" (2011:83). Estaban robando a los pobres su participación en las tierras comunales en Inglaterra, como sucedió en prácticamente toda América Latina y de manera especial en los lugares donde viven los grupos originarios, que suelen disponer de grandes recursos naturales.

En efecto, la acumulación esconde un gran abanico de procesos que incluye: la mercantilización, apropiación por la fuerza, privatización de la tierra y la expulsión por la fuerza de las poblaciones campesinas (como se dio en Inglaterra durante el nacimiento del capitalismo, como en Haití con la ocupación norteamericana del país de 1915-1934); derechos exclusivos a propiedad privada, producto del despojo; la mercantilización de la fuerza de trabajo y la supresión de formas alternativas de producción y consumo; también entraña procesos neocoloniales e imperiales de apropiación de bienes y recursos naturales.

En suma, el sistema económico, con su crédito internacional y capital financiero, se ha convertido en las verdaderas amenazas para la sobrevivencia de muchos países, por la depredación, fraude y robo que realizan de manera sistemática en esas sociedades. Apoyándose en el monopolio del uso de la fuerza y de la legalidad, como sostiene Harvey: "aquéllos desempeñan un papel importante en la aplicación de estas medidas" (2006: 26).

El capitalismo neoliberal no podría expandirse, como lo ha hecho hasta hoy, sin el consentimiento y/ o complicidad del Estado. Privatizaciones, desplazamientos de poblaciones, pérdidas de derechos anteriormente adquiridos, eliminación de acceso a bienes comunes, todo eso nos hace recordar el proceso del nacimiento capitalista durante los siglos XV y XVI que analiza Polanyi. El capitalismo logró usar el poder del Estado, cooptarlo, y ponerlo a su servicio en nombre de la democracia y en contra de la voluntad popular.

En este sistema capitalista neoliberal, las necesidades sociales, ambientales pasan a segundo término; éstas son apéndices, accesorios del mercado. Es lo que plantea Polanyi al afirmar: "una economía de mercado sólo puede funcionar en una sociedad de mercado" (2011:106).

Así la comercialización de la mano de obra y de la tierra, condición necesaria para la economía de mercado, es prueba fehaciente de una sociedad de mercado, donde la sociedad se ha escindido en dos campos, uno es lo político y el otro, lo económico, que ha logrado supeditar a ambos. Pero, como dice Polanyi:
La mano de obra y la tierra no son otra cosa que los seres humanos mismos, de los que se compone toda sociedad, y el ambiente natural en el que existe tal sociedad. Cuando se incluyen tales elementos en el mecanismo del mercado, se subordina la sustancia de la sociedad misma a las leyes del mercado (2011:108109).

La mano de obra, la tierra y el dinero no pueden ser considerados como mercancías, ya que no son producidos para la venta, y se convierten aun así en mercancías indispensables para la lógica capitalista de acumulación y para la industria; de ahí la necesidad de convertirlos en mercancías. Polanyi avanza: "ninguno de estos elementos se produce para la venta, por lo tanto, la descripción de la mano de obra, la tierra y el dinero como mercancías es enteramente ficticia" (2011:119-120).

La fuerza de trabajo es pues una mercancía falsa ya que no es producida ni reproducida para su venta en el mercado. Tampoco es posible separarla de quien la posee, y no se le puede encontrar libre en el mercado, separado de su dueño. O'Connor avanza en este sentido lo siguiente: "los seres humanos, como fuerzas productivas sociales, son organismos biológicos y sociales, no importa cuánto pretenda lo contrario el mercado de trabajo" (2001:176).

Para lograr esta conversión de seres humanos en mercancías, se requiere forzosamente que el ser humano y la naturaleza sean tratados como mercancías, como bienes producidos para la venta. Este es el objetivo y lema del sistema de mercado: El hombre convertido en fuerza de trabajo, como el caballo, la mula; la naturaleza reducida a la tierra, ambos disponibles para ser vendidos.

También se necesita de una intervención independiente o relativamente autónoma que se ponga a disposición del capital como la fuerza de trabajo humana, la naturaleza, la infraestructura y el espacio, en las cantidades y calidades deseadas, y en los momentos y lugares adecuados y requeridos.

Esta intervención no puede ser más que la del estado capitalista que produce estas condiciones y regule el acceso, el uso de la fuerza de trabajo, de la tierra, de la materia prima y otras mercancías consideradas como condiciones indispensables de producción. Como sostiene O' Connor, refiriéndose a Polanyi: “La regulación estatal de los mercados ficticios en las condiciones de producción es necesaria también porque no hay límites a la explotación capitalista de la fuerza de trabajo y de la tierra o de la gente y la naturaleza" (2001:181). 
De acuerdo con el autor de La Gran Transformación, esta lógica del mercado autorregulado, acabaría por demoler a la sociedad. Y la supuesta mercancía llamada "fuerza de trabajo" no puede ser manipulada, usada indiscriminadamente, o dejarse ociosa, sin afectar también al individuo humano que sea el poseedor de esta mercancía peculiar. Al disponerse casi enteramente de la fuerza de trabajo humano, como lo viene realizando en la actualidad, el sistema capitalista genera las consecuencias que ya visualizó Polanyi, a saber, vivir en la incertidumbre laboral, desamparo social, en la aguda dislocación.

En efecto, las previsiones de Polanyi surgidas de su análisis son hoy más que nunca reales y verídicas en gran parte: "La naturaleza quedaría reducida a sus elementos, las vecindades y los paisajes se ensuciarían, los ríos se contaminarían, la seguridad militar estaría en peligro, se destruiría el poder de producción de alimentos y materias primas" (Polanyi, 2011:134).

Apoyándonos en Polanyi (2011), podemos afirmar que el pauperismo, la economía política y la propaganda política (que ensalza los dizques logros gubernamentales) se entrelazan estrechamente para lograr tal destrucción. El pauperismo nos viene a comprobar de manera contundente e incomprensible que la pobreza parece ir de la mano con el saqueo y la acumulación; que la economía política parece responder más a los intereses de los grandes bancos, de las grandes transnacionales y centros de poder económico que a la sociedad en su conjunto; y la propaganda política parece maquillar la realidad de los pobres y encubrir muchas veces la profunda corrupción que se necesita para destruir y poner en serio peligro la tranquilidad y la paz de una sociedad.

La contradicción sigue muy patente: Al igual que en la Inglaterra del siglo XVII y XVIII, se derogó la ley de asentamiento (hoy la ley laboral) porque la Revolución Industrial requería (hoy la globalización neoliberal requiere) una oferta nacional y mundial de trabajadores dispuestos a trabajar por un salario, aunque fuera de miseria o de subsistencia; hoy en la época de la globalización neoliberal, se legaliza la suspensión o reducción de subsidios a programas del campo; el trabajo por horas con salarios mínimos, outsourcing, sin derechos de antigüedad, ni pensiones.

De hecho, la sociedad actual parece debatirse entre el doble movimiento planteado por Polanyi: una expansión del mercado capitalista neoliberal autorregulado promovida por las grandes empresas transnacionales, los grandes organismos internacionales FMI, BM, OCDE, UE, y la élite mundial. Dicha expansión encuentra, a su vez, resistencia de organizaciones de la sociedad civil, de campesinos, feministas, grupos indígenas, autóctonos a fin de proteger los derechos sociales, ambientales, culturales, económicos; de los movimientos indígenas, de ecologistas que buscan frenar la marcha de este molino satánico ante la debilidad institucional de muchos Estados de la región.

Este molino satánico, que apela a la desregulación de un mercado imponente y dictatorial tanto a nivel nacional como internacional y que al parecer nadie puede aún frenar su marcha, es insaciable: engulle, deshace y devora todo lo que encuentra. Se alimenta del el máximo sufrimiento, despojo y violación que lleva a cabo tanto a las personas como a los recursos naturales de los países dizque soberanos. Ninguna de estas acciones de saqueo y de privaciones parece ser suficientes sacrificios para satisfacer su sed de acumulación.

Las privaciones en las que viven las personas desempleadas y el miedo a quedarse sin empleo; la renuncia a los derechos humanos, sociales y económicos, aunada a la pérdida de las libertades constitucionales y a las reformas aplicadas a las Constituciones nacionales para legitimar el saqueo; todo eso se considera como un precio justo que hay que pagar para poder lograr presupuestos equilibrados y monedas sanas, fundamentos del liberalismo económico de ayer y del neoliberalismo de hoy (Polanyi, 2011). En el altar del capitalismo (neo) liberal se puede ver cómo las masas habían sido y son sacrificadas y mantenidas en la inanición por los insensibles explotadores de su indefensión.

El grado de la explotación posibilitada por el silencio, complicidad y cooptación de los respectivos gobiernos, ante la situación apremiante de la clase trabajadora regional, de la privatización de los bienes y recursos nacionales, se refleja en los bajos salarios ofrecidos a ese sector, en un aumento sensible del desempleo y de la economía informal; también se puede apreciar en la migración interna e internacional. Se da la paradoja, la cohabitación entre una catástrofe socioeconómica, socio-ambiental y una acumulación económica sin precedente.

El primer golpe o daño que asesta el sistema capitalista neoliberal a las sociedades no es forzosamente económico, sino institucional, al subordinar al Estado a sus intereses, de esta manera se da la paulatina o rápida destrucción de las instituciones. El resultado es, entre otras, una considerable y pronunciada disminución en los niveles de la vida nacional.

La expansión del mercado requiere cada vez más nuevos territorios, nuevos mercados para colocar sus productos, abaratar costos, apropiarse de recursos naturales y humanas y aumentar sus utilidades. En este sentido, la globalización es un fenómeno inherente y subsecuente de la marcha inexorable del mercado y a la vez puede ser considerado como un proyecto 
eminentemente político. En este sentido, coincido con Beck, cuando dice: "la globalización permite a los grandes empresarios volver a conquistar, someter al Estado" (1998: 16). En efecto, éstos desempeñan un papel importante en la configuración no sólo de la política sino de la economía, por no decir de la sociedad en su conjunto. Ya lo hemos visto con Polanyi, una economía desarraigada de la sociedad en un mundo global va, en aras de mayor acumulación, a socavar los cimientos de las economías nacionales y de los Estados nacionales.

La globalización neoliberal busca deshacerse, liberarse de las ataduras, limitaciones y protecciones que le había puesto el Estado de Bienestar, y regresar al liberalismo de los siglos XVIII, XIX y hasta la mitad del siglo XX; en una palabra, al totalitarismo político- económico impuesto por ese modelo. Conviene retomar la explicación dada por Herbert Marcuse en torno a ese término, afirma:

Gracias a la manera en que ha organizado su base tecnológica, la sociedad industrial contemporánea tiende a ser totalitaria. Porque totalitaria no es solo una coordinación política terrorista de la sociedad, sino también una coordinación técnico-económica no terrorista que opera a través de la manipulación de las necesidades por intereses creados, impidiendo por lo tanto el surgimiento de una oposición efectiva contra el todo. No solo una forma específica de gobierno o gobierno de partido hace posible el totalitarismo, sino también un sistema específico de producción y distribución que puede muy bien ser compatible con un pluralismo de partidos, periódicos, poderes compensatorios (1969:25).

Las dos hipótesis siguientes planteadas por este autor parecen estar casi contestadas en la era de la globalización neoliberal. Dicen:

El hombre unidimensional vacilará a lo largo de su desarrollo entre dos hipótesis contradictorias: 1) que la sociedad industrial avanzada es capaz de contener la posibilidad de un cambio cualitativo para el futuro previsible; 2) que existen fuerzas y tendencias que pueden romper este contenido y hacer estallar la sociedad (Marcuse, 1969: 17).

Esas fuerzas que pueden llevar al estallido de la sociedad son las del mercado autorregulado, como anteriormente lo había planteado Polanyi, hoy conocido como sistema neoliberal globalizado o globalización neoliberal.

Todas las áreas de la vida social muestran dos aspectos claves del neoliberalismo: una tendencia a la expansión del libre mercado ligada a la búsqueda de la mano de obra barata y otra dirigida a la extracción de riquezas vía reformas constitucionales, acuerdos y tratados comerciales, los cuales provocan el enojo, descontento de grupos indígenas, de sindicatos, de desempleados para frenar este proceso continuo de despojo generalizado. La resistencia que manifiestan estos diversos colectivos va más allá de una manifestación de enojo, sino es un reclamo para lograr cesar la barbarie, para cambiar la base política y económica sobre la que descansa la sociedad.

Al respecto Rajan avanza lo siguiente: "El mercado suele favorecer a las instituciones protegidas por el gobierno ante un eventual fracaso, les hace muy pocas preguntas y les ofrece demasiados recursos para su propio bien" (2011:203). Además, suelen conseguir garantía gubernamental de manera implícita.

La desencrustación de la economía de la política convierte a aquélla en una disciplina sin conciencia de lo social, de lo humano, de los valores sobre los cuales se sostiene la dignidad humana. Se reduce a una actividad, una disciplina rapaz, este gran remolino que traga y engulle los cuerpos gigantes para después devolverlos destrozados como nos lo relata Alan Poe en su cuento: Un descenso al Maelström. ${ }^{\text {iv }}$ Ese cuento refleja las dinámicas y las consecuencias que acarrea a su paso el modelo neoliberal.

Como ejemplo, presentamos el decálogo de dicho modelo y del Consenso de Washington, el cual consiste en borrar el debate en torno a la disciplina presupuestaria, el manejo de la inversión pública, la reforma tributaria, entre otros temas. Dice Willamson:

[...] cuanto antes obtenga la aceptación general y pueda ser eliminado del debate político principal, mejor para todos los afectados. En efecto, las probabilidades de suprimir estos temas económicos básicos de la agenda política deberían ser más elevadas que las de mantener fuera de la agenda los derechos humanos y el racismo, puesto que estos últimos dependen únicamente de juicios de valor, mientras que los mejores resultados económicos de los países que establecen y mantienen unas economías de mercado orientadas al exterior y sujetas a la disciplina macroeconómica no dejan lugar a dudas. La prueba puede no ser tan concluyente como la que la Tierra no es plana, pero está bastante bien fundamentada como para que la gente juiciosa tenga cosas mejores que hacer con su tiempo que dudar de su veracidad (1993:1330).

El Consenso de Washington a través de sus postulados de Libre Mercado y Democracia; Privatización e IED contribuyeron a transformar a América Latina en un continente marcado por sangre y por millones de empobrecidos.

Las causas de ese fenómeno remontan a la aplicación de dicho decálogo, lo cual llevó al desmantelamiento sistemático y cancelación de los derechos sociales operados por los Estados cooptados y coludidos por las grandes empresas nacionales y transnacionales y por el sistema financiero draconiano, parecido 
al remolino satánico de Polanyi y de Poe.

El modelo neoliberal ha instalado la neo-esclavitud combinada con la precariedad, la incertidumbre como modo de vida y sin olvidar las consecuencias psicológicas, sociales, familiares y políticas que acarrea. La conciencia social no se erige sólo sobre la situación de desigualdad y de pobreza que viven las personas sino se construye también a partir del mercado oligopólico y con todas las artimañas que eso entraña: corrupción, sobornos a todos los niveles de las instituciones estatales y despojo, entre otras prácticas dañinas para la construcción y cohesión social.

Es un modelo económico autoritario que necesita escasa legitimidad y mucha corrupción; manipulación, fraudes, violencia y miedo para someter a todos a su voluntad. Busca convertir a la sociedad en una sociedad vorazmente consumista e individualista, con ciertos disfraces de gobernanza y de participación ciudadana.

En efecto, la globalización neoliberal se nutre de falacias y de mentiras. El crecimiento económico va de la mano con el desempleo, la pobreza y la miseria; y la disminución de impuestos a los ricos a fin de que éstos creen empleos acaba por generar también más desempleos. Habría que leer y comprender ese modelo no desde lo que pregona y dice, sino desde los amargos frutos que produce, desde los estragos que genera.

Hoy todo se privatiza o es privatizable. Es la anarquía de la expansión mercantil. La globalización neoliberal no es otra cosa que un saqueo disfrazado de comercio y de inversión. De acuerdo con Harvey (2003), lleva entre nosotros al menos desde 1492.

Una vez, apropiándose de los Estados nacionales, tanto las mercancías como los puestos de trabajo pueden circular de un país a otro, buscando mano de obra barata y cargas fiscales ad hoc a su lema: capital sin impuestos es igual a aumento de la acumulación, o de plano impuestos inexistentes o muy insignificantes. Hace irrupción ante nosotros una nueva división global internacional del trabajo, donde los Estados nacionales se ven impelidos a crear infraestructuras y aceptar condiciones para facilitar la explotación de sus propios recursos o mano de obra. En caso de que no quiera cooperar con las "inversiones del capital", el Estado se ve castigado por las grandes empresas transnacionales, los organismos económicos internacionales y afines. Este es el verdadero molino satánico, al que aludía Polanyi.

El surgimiento y fortalecimiento de la globalización neoliberal dentro del mercado autorregulado no se podría dar sin una acción política para su implementación y sin el fortalecimiento de las corporacio- nes transnacionales, las cuales dan forma y consolidan los procesos globalizantes. Junto con ellas, encontramos al Estado, que se ha convertido en un servidor de las transnacionales al buscar regular los movimientos migratorios que se dan dentro y a través de las fronteras nacionales. Esta sociedad global neoliberal, afirma Beck:

Se ha ramificado de manera exponencial y se entremezcla con el Estado nacional y al mismo tiempo lo relativiza, ya que cuenta con redes de comunicación, relaciones de mercado y modos de vida que traspasan en todas direcciones las fronteras territoriales del Estado nacional (1998: 19).

Los grandes luchadores y defensores del crecimiento económico buscan impedir o reducir a su mínima expresión la participación del Estado en el ámbito económico (también social, cultural, entre otros) para así mantener y hasta ampliar la enorme brecha hoy existente entre las clases sociales a nivel nacional como internacional. Esta reducción se refleja en gran parte en las exenciones de impuestos y prestaciones que el Estado les otorga en aras a que aquéllos crean fuentes de empleo. En este sentido, el capitalismo neoliberal globalizado ha sabido superar al anterior capitalismo liberal, al crear una forma sui generis de aumentar su capital sin crear empleo y sin pagar impuestos o pagar un simulacro de impuestos. Han logrado además que el Estado los recompense por los saqueos, destrucciones causadas a las economías nacionales.

$\mathrm{Al}$ estar virtual y financieramente presente, $\mathrm{y}$ casi en todas partes, el mercado autorregulado, provoca dislocación y desintegración social en los países donde se inserta. La urdimbre del tejido social construido en la era del Estado nacional y de Bienestar se ha roto con la globalización neoliberal financiera y sociocultural. Si la rapidez en la movilidad y translocalización de bienes y servicios del trabajo y del capital es nueva, también lo es la dislocación social que sufren las sociedades actuales y con sus respectivas consecuencias en los Estados-nación.

Hemos insistido en que las grandes empresas transnacionales al igual que los grandes organismos internacionales son piezas fundamentales en la economía global de mercado. Colocados por encima del Estado nacional, imponen sus condiciones a las sociedades sin que éstas tengan la oportunidad de debatirlas o de formular sus propuestas. Es la dictadura del mercado disfrazada de fachadas democráticas.

Mientras que las empresas transnacionales se lanzan en una lucha competitiva sin cuartel, buscando desarrollar mejores tecnologías, apoderándose de la mano de obra más barata sin prestaciones sociales y de los recursos naturales sin límite alguno, los orga- 
nismos internacionales piden a los países en vías de desarrollo mayor apertura, mayor flexibilidad laboral y mejores resultados en el combate a la inflación, en detrimento de la necesidad del país. Esta competencia instala e incrementa la inestabilidad y la incertidumbre, lo que Mittelman denomina el darwinismo social (2002: 33), y nosotros lo podríamos nombrar esquizofrenia social. De esta forma, el capital global hace prácticamente añicos la autonomía del Estado. Su capacidad de realizar el movimiento de proteger a la sociedad (el doble movimiento polanyiano) contra los embates y la salvaje expansión del mercado se reduce. Con respecto a los países más pobres, dice Mittelman: Un indicador clave de su incorporación a la división global del trabajo y al poder global es el flujo de financiamiento no sólo hacia prestamistas privados, sino también hacia aquellos relacionados con los programas de ajuste estructural que exigen las instituciones financieras internacionales que no es sino una manera de disciplinar a las naciones (2002:39).

Como lo hemos comentado arriba, la globalización neoliberal conduce al Estado a llevar políticas económicas que responden más a las presiones y exigencias generadas por el capitalismo transnacional que a las necesidades de su propia población.

A diferencia de la economía mundial de los años treinta analizada por Polanyi, su anhelo de enraizar o re-enraizar la economía en la sociedad suena hoy casi imposible, o un sueño difícil de hacer realidad, debido precisamente a una globalización neoliberal totalmente desarraigada. Y una de sus consecuencias que provoca es la emigración, ya que la gente busca huir de la violencia, del hambre, del saqueo de sus riquezas naturales y del desamparo.

\section{Globalización, Migración y Exclusión Social}

Esa globalización neoliberal va a agravar y aumentar la desigualdad social mundial y también en el ámbito estatal-nacional (Beck, 2008). Efectivamente la brecha entre poseedores y desposeídos se agranda tanto dentro de los países de primer mundo como entre éstos y el resto del mundo que sirve por lo general como proveedor de materias primas, como países de extracción de riquezas minerales. Para apropiarse de esos recursos, despojar a los habitantes de ellos, suelen recurrir a la violencia, la cual obliga a muchos a la migración interna e internacional, huyendo de la miseria y de la muerte.

Si el Norte despoja, hacia allá se dirigen esas personas migrantes para poder sobrevivir y mejorar su calidad de vida, pese a todos los malos tratos, abusos y actos discriminatorios que sufren y enfrentan con heroísmo salpicado de resignación.
En este sentido, las prácticas culturales de esas sociedades expulsoras son un recurso indispensable para fomentar y reforzar los vínculos étnicos, nacionales entre ellos y abrirse paulatinamente a las prácticas culturales de la sociedad receptora.

Habrá que mencionar que, al llegar allá a Estados Unidos -si tienen la suerte-, se encuentran con el mismo modelo económico que aplica el desmantelamiento de los derechos sociales; se dan cuenta de que pertenecen a los más pobres entre los pobres globales, teniendo quizás ciertas oportunidades de trabajo y ciertos derechos a salvo en el país de acogida. Ésos suelen verse por parte de los grupos conservadores como una concesión hecha a unos supuestos enemigos potenciales, llamados inmigrantes pobres. Aquéllos alimentan el miedo de que, con la presencia de aquellas personas migrantes, las personas nacionales van a sufrir una reducción en su nivel de vida y bienestar social, lo cual es una falsedad.

Esa situación suele generar y esconder un conflicto durmiente, muchas veces latente y otras veces, declarado, cuyas consecuencias son asesinatos de migrantes, abusos, deportaciones masivas, rechazo social, entre otras. De hecho, los asesinatos recientes de migrantes tanto en Estados Unidos como en Europa nos han dado tristemente testimonio de estos crímenes contra las personas migrantes.

Existe una amnesia consentida por parte de los sectores conservadores al olvidar que vivimos en una economía neoliberal globalizada por ellos mismos con algunos tintes mercantilistas, como dice Rodrik: "donde las empresas y el Estado podían satisfacer sus intereses mutuos y así la economía se convierte en una herramienta de la política y viceversa" (2011:30). Empero, ya vimos lo que generó en el siglo XVI en Inglaterra con los Tudor, donde el poder político y económico se convierten en lo mismo, se entrelazan y se confunden, convirtiendo al Estado en rehén de este grupo.

El Estado es imprescindible para atacar estos problemas arriba mencionados y a la vez es indispensable para la implementación del modelo neoliberal, cuyo objetivo no es la promoción y protección de los derechos sociales de las personas. Paradoja de la cual no podemos salir, al parecer, sino buscar instalarnos de la mejor manera en ella, con creatividad y con la mirada puesta en la desigualdad social.

Si la globalización son los rieles sobre los cuales corre el tren capitalista neoliberal financierista, extractivo, especulativo y depredador, le conviene a los Estados revisar tanto la calidad de los rieles, regular la velocidad con la que va ese tren y los daños que deja en su camino: de paso, modificar su rumbo paulatina- 
mente, como se hizo en la década de los años cincuenta del siglo pasado. Mercado y gobierno se necesitan: son como dientes y lengua, necesarios para alimentar y mantener con vida el cuerpo humano, en este sentido la sociedad. Si no se logra esta complementariedad, ese cuerpo sufrirá de hambre, de anemia y de enfermedades crónicas, como lo podemos observar en la realidad.

En efecto, ésta da testimonio de las desigualdades de condición, de riqueza y de conocimiento, como lo menciona Milanovic (2016); unos pocos tienen todo y los muchos tienen muy poco o nada.

Una significativa reducción de la emigración indocumentada está íntimamente ligada a una desigualdad positiva, o buena, es decir crear mecanismos para que las personas empobrecidas de sus respectivos países puedan dignificar sus vidas a través del empleo, del estudio y de la creación de medios de sustento que les pueda permitir vivir con frugalidad. Si la misma lógica neoliberal sigue, seguirá también la emigración y su corolario de atropellos, de discriminaciones múltiples, basadas en el nivel económico, educativo; en el sexo, en lo fenotipo y en el lugar de nacimiento.

La gran mayoría de los que emigran forman parte de esos condenados de la tierra, de los que habla Frantz Fanon; para esos sentenciados es el último recurso para no morirse de hambre y a causa de la guerra; para los privilegiados del sistema, para los grandes empresarios, es un medio para aumentar su capital a través de la mano de obra barata colocada fuera de la ley.

Conviene recordar que gran parte de la emigración actual se da en un contexto de criminalización de las personas que son víctimas de ese despojo y saqueo legalizados; en una palabra, de esas decisiones político-económicas y financieras que les condenan a la pobreza, a la emigración o a la delincuencia organizada. En la era de la globalización neoliberal, la circulación de las élites (Milanovik, 2016) y de sus mercancías y bienes se realiza con todas las protecciones y cuidados posibles; mientras que los pobres son maltratados, estigmatizados, criminalizados y discriminados, cuando muchas veces los factores de expulsión se deben a la rapacidad y voracidad de esas decisiones político-económicas que causan desempleo, precariedad, hambruna, violencia y guerra en sus países de origen.

En este sentido, tiene razón en gran medida Milanovik cuando afirma: “... son los factores económicos los que están detrás de la emigración” (2016:145), y los que se desprenden de ellos. También esos factores que producen tanta desigualdad están detrás del desencanto hacia la democracia, de la falta de confianza y de credibilidad hacia las instituciones del Estado. En una palabra, se esconden detrás del Estado cooptado por las élites de poder económico y político, donde el $10 \%$ más rico del mundo reciben el $56 \%$ de la renta global, mientras que el 10\% recibe sólo el 0.7\%, de acuerdo con Milanovik (2016).

¿Cómo obligar a las personas empobrecidas a quedarse en sus lugares para ser asesinados por la violencia, la guerra, por el hambre y por las enfermedades curables? No basta con la criminalización de esas personas ni con la construcción de muros; ni con culparles de su pobreza (Munk, 2005). Es una lucha perdida de antemano, lo que se requiere es reducir o combatir la desigualdad dentro de los países y también la reducción de las diferencias de los niveles de renta media entre países, como menciona Milanovik (2016).

Mientras tanto, los desposeídos se seguirán moviendo (eppur si muove y, sin embargo, se mueve) dentro de esta exclusión social global que acrecienta el sistema neoliberal, con su mercado autorregulado, lo cual es una falacia.

Inestabilidad recurrente, grandes privaciones causadas por el mercado autorregulado, con la complicidad y corrupción muchas veces de los Estados y de sus respectivas élites, suman en la miseria a millones de personas, mientras que las élites, como sostiene Munk (2005), detentan una fuerte concentración de riquezas. En este sentido, es importante subrayar que el crecimiento económico es necesario y si no viene acompañado de una política económica redistributiva puede incrementar los niveles de desigualdad en los países (Munk, 2005), la cual genera el empobrecimiento, violencia y emigración.

Estos se incrementan a la misma velocidad que el saqueo neoliberal, al negarles su condición humana. De esa forma, las personas empobrecidas sufren una humillación por rebajamiento y al no poder formar parte del mundo de los derechos, sufren otra humillación conocida como negación de la igualdad, la cual conduce a la exclusión (Badie, 2014). Sus vidas se parecen a lo que denomina Agamben (1998) vida de excepción, nuda vida, más cercanas al zoé que al bios, a la que cualquiera puede dar muerte. Esas personas empobrecidas, invisibles socialmente y necesarias económica y políticamente suelen encontrar y vivir la misma segregación, discriminación institucional y social negación de derechos y marginación social en el país de destino, debido a múltiples factores, tales como nivel económico y de estudio; ser irregular, su género y su fenotipo entre otros. Esas personas cargan con su pobreza, también con su esperanza y su deseo de vivir. La pobreza suele ser un impedimento para 
tratar al otro con dignidad, como si no fuera un ser humano; suele causar rechazo, medio, más aún cuando se mezcla con diferencias fenotípicas piel morena, o negra y de género, ser mujer.

Desde la abismal polarización social, debido a la desencrustación de la economía de la sociedad, planteada por Polanyi, los derechos humanos difícilmente pueden ser aplicados a las personas migrantes pobres por la estigmatización, relegación y rebajamiento que sufren, ya que se les niega el derecho de ser y de existir; no miramos en ellas la dignidad de todo ser humano sino los estragos de la pobreza que surcan y marchitan su rostro y si se mezcla con un fenotipo no bien visto desde el canon de belleza impuesta en ese país receptor, la sentencia está ya dictada para esas personas.

Los migrantes se encuentran en un estado de excepción, vaciado de derechos. Este estado está carente de derechos (Agamben, 2004), mientras que a otros les sobran derechos. Es una contradicción inherente al sistema neoliberal, a mayor polarización social y empobrecimiento, demasiado derechos para unos pocos, mucho optimismo por parte de los que causan estos daños y se benefician de este modelo económico, como lo plantea Munk (2005).

Esa polarización arriba mencionada es también consecuencia de la flexibilidad, precariedad e inseguridad laboral en las que vive la inmensa mayoría de la población mundial. Esas formas de inserción laboral se han convertido en el nuevo credo de la globalización neoliberal capitalista para mantenerse competitivos, o, en términos de Munk, "pueden hasta ser vistas como virtudes" (2005:147).

Esas actitudes virtuosas del capitalismo neoliberal que orillan a millones de personas a emigrar suelen estar esperándolas en el país receptor. Es lo que analizaremos en el siguiente apartado.

\section{La difícil convivencia entre migrantes y nativos}

La vivencia de las personas migrantes empobrecidas que cargan con su nuda vida se da en general en un contexto de exclusión y humillación. De entrada han de enfrentar y sortear diversas desventajas (Zanfrini, 2007), desde su fenotipo, al cual nos hemos referido y una negación de igualdad, la cual se sostiene desde una ideología antiinmigrante y se nutre de la estigmatización del "extraneus: extranjero", que desde la mitología griega era un protegido de Zeus, que merece la hospitalidad de los nativos, y que se ha convertido ahora en un extrarius, alguien que busca desafiar al soberano y se convierte en supuestos enemigos de la nación receptora. Esta estigmatización logra muchas veces permear y moldear el sentir y el comportamien- to de este grupo; en una palabra, el proceso de socialización institucional y la ideología discriminatoria y humillante afectan y restan capacidad de agencia a las personas migrantes.

Hoy el indocumentado, irregular no es otra cosa que el extrarius en la era de la dominación de la aporofobia (miedo a los pobres, empobrecidos) disfrazada de lo legal-racional; es un desterrado por el hambre, excluido del derecho y considerado por su nuda vida. No es que la sociedad receptora no reconoce en ellas, su ser personas, sino la construcción del imaginario social instituido e instituyente encasilla a las personas inmigrantes, lo cual es una creación social-histórica y cultural (Castoriadis, 1975). Esa actitud se relaciona con la institución del imaginario social, de las significaciones imaginarias (Castoriadis, 1985) atribuidas a un grupo de inmigrantes. Las instituciones y los medios de comunicación del país receptor, por su parte, se encargan de recrear y revivir dicho imaginario en las relaciones sociales entre nativos y migrantes.

Dichas relaciones están marcadas por prejuicios morales, étnicos, por tratos discriminatorios y fenotípicos. En cuanto a los prejuicios, la palabra nos indica que es un procedimiento que antecede el juicio; no da lugar a la observación, al acercamiento con esta persona, con esta realidad, sino que aplica las categorías del imaginario social instituyente e instituido por la élite dominante para clasificar y encasillar a las personas con rasgos diferentes y construir una frontera sociocultural, simbólica y física para que la sociedad pueda diferenciarse y tomar distancia de ellas y así sentirse protegida. Sentirse a salvo tanto en sus espacios como en sus privilegios y de esa manera reafirmar su sentimiento y convicción de superioridad como nacionales sobre aquellas personas migrantes.

Así, las características visibles de una persona, como su color de piel, idioma, entre otras, determina en gran medida su dignidad humana y la calidad del trato que puede y ha de recibir y eso suele valer también para el grupo al que pertenece. El prejuicio descansa sobre y se nutre de los estereotipos y ambos tienden a generalizar, a extender sus sentencias a todos los miembros del grupo que son considerados como intrusos e inferiores. En este sentido, tiene razón Zanfrini, al afirmar: "El prejuicio se relaciona con nuestro modo de organizar la realidad para darle sentido" (2007:73).

Por otra parte, las personas migrantes suelen ser víctimas de la discriminación institucional y social. Ésta abre la puerta a los atropellos, abusos, explotaciones que viven, ya que son consideradas como supuestos enemigos, invasores sociales, que vienen a 
mermar el bienestar social de los nativos y las arcas del Estado; muchos sectores de la sociedad receptora suelen justificar y hasta aprobar algunas violaciones y vejaciones cometidas hacia ese grupo. De esa manera, la discriminación social refleja y corrobora ese imaginario social instituyente e instituido que niega el goce de los derechos humanos a los que no son como los nativos. Esas personas que provienen de países pobres y empobrecidos están atrapadas en una doble invisibilidad: invisibles son los abusos, insultos, maltratos y atropellos que sufren por parte de algunos sectores de la sociedad; además no tienen los medios para hacer escuchar sus voces, denunciar esas vejaciones y afrentas que sufren.

Si bien el nivel educativo y profesional juega un papel fundamental en el desempeño laboral y social de las personas inmigrantes, también no podemos negar la discriminación institucional que incluye la estadística con sus sesgos de fenotipo, de proveniencia; ni la discriminación social manifestada en actitudes y acciones xenófobas que constituyen enormes barreras difíciles muchas veces de superar, de franquear por parte de la mayoría de ellas. Esos factores adversos impiden en el fondo una inclusión social de esas personas migrantes, por lo menos las de la primera generación., y no se trata sólo de la escasez de instrucción, ni de la distancia cultural entre las personas inmigrantes y las nativas, como lo sostiene Zanfrini (2007), además el rebajamiento y el desprecio hacia sus culturas hacen que les orillan a vivir muchas veces en un tipo de encierro sociocultural y socioeconómico, no por falta de capacidad sino por negación de derechos y de oportunidades por su fenotipo, su origen y hasta su género.

En el plano socioeconómico suele darse una etnicización de ciertas actividades laborales, como el trabajo agrícola, construcción, donde la informalidad y la precariedad son la norma. Por lo general, encontramos a las personas inmigrantes en los niveles socioeconómicos más bajos. De esta manera podemos afirmar que ellas no son un peligro sociocultural ni socioeconómico para el país receptor, sino que sus vidas corren peligro por sus múltiples diferencias (además de su pobreza) que desde el criterio del país receptor no son dignas de ser respetadas.

Olvidamos que una o la principal y verdadera amenaza para todas y especialmente para las personas migrantes es la aplicación de ese modelo económico impuesto llamado neoliberalismo. Las personas migrantes sirven como banderas falsas, chivos expiatorios que cargan con los problemas y las crisis sociales y económicos que atraviesa el país receptor. Hay que construir un enemigo visible y a la vez débil y sin voz, mientras que los verdaderos quedan en el total anonimato.

La construcción de unos enemigos a modo a partir de unas diferencias fenotípicas, socioculturales y económicas se fundamenta y se explica desde una supuesta identidad homogénea, unitaria; predispone y prepara el camino para la discriminación y la criminalización hasta el asesinato de las personas que no son parte de esa identidad supuestamente homogéneas. Esa violencia desempeña, al decir de Lanceros (2014), una función conservadora. La alteridad es negada, la alteración del supuesto orden da miedo, el último recurso es el altercado, la violencia. La suerte de las personas migrantes se debate en este triángulo de las tres A: alteridad, alteración y altercación.

La imposición de la globalización neoliberal y el mercado autorregulado, estudiado por Polanyi, no sólo rompe la cohesión y el tejido social, ensancha la polarización en prácticamente todos los países expulsores de migrantes y también en los países receptores que los ven a éstos como una amenaza para su bienestar social y su identidad nacional. Bajo esta lógica, la institucionalización de la discriminación y de la violencia se vuelve eficaz para mandar una señal a las personas nativos que el Estado o el gobierno está combatiendo a sus supuestos enemigos. De esa manera dicho gobierno tiene todo el camino libre para reforzar todos los mecanismos de violencia hacia esas personas intrusas.

Esta violencia sistemática y necesaria deja además buenos dividendos económicos y políticos a los que la azuzan y la justifican. El recurso a la violencia es buscar recuperar un tiempo perdido, vivir en el pasado y no aceptar el presente; como dice Lanceros: "La violencia viene siendo la memoria, la nostalgia y el anhelo del orden" (2014:24). Sobre las personas inmigrantes se suele descargar esa frustración de recuperar el pasado, el orden y la unidad perdidos.

Esa violencia se manifiesta en el lenguaje, en los medios de comunicación masivos, en las redes sociales y desde luego en la ciudad, que impone modos y modas de vivir. Conviene decir que aquélla existía ya antes de la llegada de las personas inmigrantes, ahora encuentran en ellas a unas víctimas que constituyen una amenaza construida a modo y que está de moda. Las ciudades administran y estructuran sus necesidades, sus miedos y sus trabajos; les recuerdan a los inmigrantes quiénes mandan y que no sólo son representaciones sino presencias, que se imponen a esas personas migrantes con todas sus fuerzas coercitivas, con sus posibilidades de alteridad, de altercación y de negación de derechos. 
Por otra parte, la discriminación étnico social y económica se compone de un fuerte comportamiento biológico, es decir inmunológico, donde las relaciones están marcadas y atravesadas entre nativos y emigrantes; entre el de adentro y el de afuera, el amigo y el enemigo o entre lo propio y lo extraño (en lo social se sigue dando). Ataque y defensa determinaban el procedimiento inmunológico: repeler todo lo que es extraño. Byung-Chul afirma: "el objeto de la resistencia inmunológico es la extrañeza como tal. Aunque cuando el extraño no tenga ninguna intención hostil, incluso cuando de él no parta ningún peligro, será eliminado a causa de su otredad" (Byung-Chul, 2012:12). Otredad entendida en el campo migratorio, como su origen, su pobreza, fenotipo, entre otras características que llevan consigo las personas migrantes.

El discurso social y migratorio se sirve de manera intencional y explícita de modelos explicativos procedentes del campo inmunológico, aunque como afirma Matzinger "el objeto de la Resistencia inmunológica ya no consiste en la extrañeza o la otredad como tal, sino que se repele únicamente al intruso que se comporte de manera destructiva en el interior de lo propio" (Byung-Chul, 2007:11-13).

De acuerdo con este autor, el sistema inmunitario biológico es más generoso de lo que se pensaba con respecto a la manera de comportarnos nosotros los seres humanos frente a las personas migrantes; pues dicho sistema no es xenófobo y por ende más sabio que nosotros, como sociedad humana; por tanto, es más inteligente que la sociedad humana, que practica la xenofobia y la negación de derechos a las personas migrantes. Esta corresponde a una reacción inmunitaria patológicamente exagerada que es nociva incluso para el desarrollo de la misma sociedad, humanidad. Nocivas son las actitudes que les consideran como nuda vida, personas que viven en estado de excepción, donde la hospitalidad cede lugar a la hostilidad, a lo inhóspito y donde se tambalea y se vacía de dignidad humana la existencia de esas personas.

\section{Conclusiones}

En definitiva, la migración es un fenómeno igual de antiguo como el ser humano mismo; lo novedoso de este fenómeno es que, con la globalización neoliberal y la crisis financiera, dicho movimiento adquiere una magnitud distinta y connotación diferente y afecta a todos los países del mundo, tanto como emisores, receptores o países que son de tránsito para las personas migrantes (Álvarez, 2010).

En efecto, en un sentido polanyano, la extensión del mercado laboral y la movilidad del capital tal desgarran la urdimbre social e inserta nuevas polaridades entre quienes reciben las remesas y que pueden adquirir diversos bienes de consumo y quienes no. Los y las trabajadores inmigrantes y su familia, enredados en una estructura compleja de dependencia son mercancías como muchas otras que se venden en un mercado regional y global y son un eslabón en la cadena de mercantilización del capitalismo neoliberal. Estos flujos de mano de obra que recorren a diario el continente son reflejo de la movilidad del capital, de los eslabones indispensables y desechables a la vez para las cadenas mercantiles globales, y sirven como indicadores burdos de la posición en las estructuras geoeconómicas (Mittelman, 2002)

De esa manera, podemos percatarnos de que se teje una relación estrecha entre sistema capitalista neoliberal, globalización y migración. De hecho, la migración se mueve hacia donde está y se desplaza el capital. Constantemente se reconfigura y se reestructura la economía política global, y también la migración, pese a las múltiples restricciones que le ponen, como podemos atestiguar con la caravana de los migrantes centroamericanos que cruzan México para poder llegar a Estados Unidos de América durante los meses de octubre- noviembre de 2018 y que continúa hasta hoy en la actualidad. Esta movilidad de esas víctimas de la violencia política y de la política de la violencia determina e indica la jerarquía de poder dentro de una región o de un continente; en una palabra, muestra quién manda. Y la ubicación de un área en la división global del trabajo y del poder, así como sus formas de especialización, influyen en las condiciones para la salida e ingreso de mano de obra migratoria. Estas interacciones tienen profundas implicaciones en la distribución, desigualdad y justicia social a escala mundial y regional (Mittelman, 2002).

En esta misma línea de idea, ser país periférico apunta más a las relaciones marginales existentes entre los grupos que participan en el proceso de producción para el centro. Si la periferia desaparece, por su agotamiento de su subsuelo, deforestación, fuga de cerebros, conflictos sociopolíticos, etc., ¿qué será del centro? ¿Es inagotable la periferia, o es inacabable e inabarcable la riqueza del Centro?

Entre los diversos efectos ocasionados por la globalización neoliberal en el contexto de la migración y de la nueva división global del trabajo, debido al desarraigo de la economía de mercado, podremos enumerar los siguientes: "Las estructuras sociales cambiantes y los patrones de violencia social y de conflictos de todo tipo; la inestabilidad política, las explotaciones, las discriminaciones, la desintegración familiar y el impacto en la producción agrícola y am- 
biental" (Mittelman, 2002:97).

Si bien la Comisión Económica para América Latina (CEPAL) afirma que la migración es una manera de reducir la diferencia de ingresos en el mundo y sostiene que la emigración ayuda a liberar presiones demográficas, mitiga el desempleo, y encauza las remesas al país de origen, entre otras (Cepal, 2019); lo que sí ha ayudado es a paliar un poco el hambre y a cubrir las necesidades básicas de las familias en los países receptores, creando a largo plazo una dependencia tanto a nivel familiar como social; de paso quitándole su responsabilidad social al Estado.

De hecho, a la larga, la dinámica migratoria crea más dependencia del exterior e impide que los propios nacionales desarrollen sus capacidades dentro de sus respectivos campos. También es bueno enfatizar que el bono demográfico y de talento humano se va mermando, como empieza a ser el caso de muchos países de América Latina y sin contar la constante fuga de cerebros que registra la región. La explicación de todo proceso migratorio reside en las causas estructurales que lo generan. Son éstas que hay que atacar si queremos revertir el proceso migratorio.

En efecto, las consecuencias nefastas ocasionadas por el Programa de Ajuste Estructural (PAE) dejaron muy pocas opciones para los países empobrecidos, como ya lo hemos analizado. A cierta distancia histórica de las famosas reformas aplicadas en América Latina y en el Caribe, nos podemos percatar de que es casi imposible la convivencia o coexistencia entre democratización y globalización neoliberal.

Jeremy Bentham clasificó a los empobrecidos de la Inglaterra de su época en tres grupos: "Las manos fuera de lugar", que corresponden a los recién despedidos y se distinguen del estancamiento casual. El "estancamiento periódico de los trabajadores estacionales se distingue de las "manos sustituidas" o desempleados por la aridez de la tierra, el cierre de maquiladoras debido a problemas sociopolíticos y de infraestructura; por último, encontramos las " $m a$ nos desbandadas" son las que huyen de los conflictos sociales, revueltas, hambre o epidemia" (Polanyi, 2011:160). Este paralelismo y estos términos pueden ayudar a pensar y comprender mejor la problemática de la migración, que como la globalización, tiene una dimensión político-económica.

Estos tres tipos de "manos" arriba mencionadas constituyen y se refieren en gran parte a las personas migrantes internacionales quienes, al llegar a los países receptores, están propensas a sufrir muchas veces de estigmatizaciones, discriminación étnica y violencia.

¿Qué sería del sector de la construcción, de la agricultura sin la mano de obra de mujeres y hombres migrantes irregulares en los países desarrollados y con mejor nivel de vida que sus vecinos; sin la mano de obra de las y los mexicanos y latinos en general en Estados Unidos?; ¿ sin la de los nicaragüenses en Costa Rica, sin la mano de los dominicanos y ecuatorianos en España? Pero una vez que los inmigrantes quedan a merced de los empresarios y de los empleadores, por ser simple mercancía, el reto consiste en cómo sacarles de la invisibilidad social e institucional, es decir cómo restringir y poner un freno al sin fin de abusos, explotaciones sufridos por parte de aquéllos.

También una vez que gran sector de la economía del país receptor se ha vuelto adicto a la mano de obra migrante irregular, muchas instituciones de ese país suelen subordinarse a esa lógica de la economía de mercado sin dejar de ejercer la discriminación institucional y social. De hecho, las instituciones son materializaciones de significantes y significados; propósitos humanos que encierran una carga histórica que dotan de sentido al quehacer cotidiano y político.

En efecto, están dotadas de mucho sentido las crisis que se dan dentro de la expansión del mercado autorregulado que obligan al capital y a los países tanto receptores como expulsores y de tránsito a enfrentar sus propias contradicciones básicas, entre ellas la emigración, la inmigración, y la migración de tránsito que subsecuentemente se desplazan a la esfera política, ideológica, cultural (género) y ambiental (O’ Connor, 2001).

Neoliberalismo, globalización y migración son tres elementos constitutivos de la acumulación del capital y de la nueva división global del trabajo y del poder, basada en la extracción y en la necropólitica, entre otros más factores.

En la década de los treinta, muchos, asustados por el ascenso del comunismo, vieron en el fascismo un remedio contra los excesos y abusos del liberalismo, ¿cómo enfrentar hoy los embates nocivos del capitalismo neoliberal actual sin caer en un nuevo tipo de fascismo o nazismo?

Los casos recientes de manifestaciones contra este modelo a finales del 2019 y principio del 2020 en Ecuador, Colombia, Haití, Chile, Francia, exigiendo poner un freno a ese molino satánico, a través de un cambio en el modelo económico, a través del reclamo de no más privatizaciones y demanda de mayor inversión en lo social, de mayor respeto y cuidado al medio ambiente; a la soberanía de los países para que puedan tener mayor control sobre sus recursos, entre otras exigencias. Hoy ese molino se ha caracterizado por sus procesos de privatización y por la precariedad social y laboral. A través de estos incipientes reclamos 
quieren ponerle un freno a ese modelo económico. El golpe de Estado orquestado contra Evo Morales en Bolivia para frenar los logros sociales obtenidos durante su período; la victoria de Andrés Manuel López Obrador como presidente de México en las elecciones del primero de Julio de 2018, seguida de la toma de posesión el 1 de Diciembre del mismo año, después se dio la victoria de Alberto Fernández en Argentina y la victoria de Bolsonaro en Brasil, el Primero de Enero de 2019, son el reflejo de las nuevas y tensas correlaciones de fuerza que hoy se dan en todo América Latina y que acentúan la crisis de ese modelo económico, cuyos principales efectos están expuestos en este trabajo. Las que los sufren más que nadie son las mujeres, las niñas y niños. En ellas se reúnen y se manifiestan todos los rasgos y efectos de la negación de derechos institucionales y sociales, de la necropolítica, entendida, retomando a Estévez, como: "un conjunto de políticas y leyes ejecutadas para producir situaciones, momentos y espacios que fuerzan a las personas a dejar sus hogares, o las orillan a situaciones y espacios de muerte" (2018:2). Este tema sería el objeto de un futuro análisis.

\section{Referencias}

Agamben, Giorgio, (1998). Homo sacer: el poder soberano y la nuda vida, Pre-textos, Valencia, España.

Agamben, Giorgio, (2004). Homo sacer: Estado de excepción, Pre-textos, Valencia, España.

Alvárez Acosta, María Elena, (2010). "El capitalismo y las migraciones humanas: propuestas para un análisis", en Migraciones internacionales en el mundo contemporáneo, Estudio de casos, Universidad de Quintana Roo.

Amarela Varela Huerta, (2017). "La trinidad perversa de la que huyen las fugitivas centroamericanas: violencia feminida, violencia de estado y violencia de mercado", Debate feminista, número 53, pp. 1-17 Universidad Autónoma de la Ciudad de México, Ciudad de México, México.

Badie, Bertrand, (2014). Le tempos des humilliés, Pathologie des relations internationales, Paris.

Beck, Ulrich, (1998). ¿Qué es la globalización? Falacias del globalismo, respuestas a la globalización, Paidós, España.
Beck, Ulrich, (2008). Generación Global, Paidós, España.

Boltanski y Chiapello, (2002). El nuevo espiritu del capitalismo, Akal, Madrid, 2002

Byung-Chul, Han, (2012). La sociedad del cansancio, Herder, Barcelona, España.

Castoriadis, Cornelius, (1975). L'Institution Imaginaire de la Société, Editions du Seuil, Paris, France.

Castoriadis, Cornelius, (1985). "Reflexiones en torno al racismo", En el Coloquio "Inconsciente y cambio social" de la Association pour la Recherche et intervention Psichosociologiques.

Comisión Económica para América latina (CEPAL, 2019). Desarrollo y Migración: Desafíos y oportunidades en los países del norte de Centroamérica.

Estévez, Ariadna, (2018). "El dispositivo necropolítico de producción y administración de la migración forzada en la frontera Estados Unidos-México", Estudios Fronterizos, vol. 19, 2018.

García Canclini (2001). La globalización imaginada, Paidós, México.

Giddens, Anthony, (2000). Un mundo desbocado, los efectos de la globalización en nuestras vidas, Taurus, Madrid, España.

Harvey, David, (2006). "La acumulación por desposesión”, en Espacios globales, Universidad Iberoamericana, pp. 21-52.

Harvey, David, (2000). Espacios de esperanza, Edición Akal, Madrid, España

Lanceros, Patxi, (2014). Orden sagrado, santa violencia, teo-tecnologías del poder, Abada: Madrid, España.

Marcuse, Herbert, (1969). El hombre unidimensional, cuarta edición, México.

Matzinger, Polly (2007). "Friendly and dangerous signals: is the tissue in control?", en Nature immunology, vol. 8, núm. 1, Enero, pp.11-13)

Milanovic, Branko, (2016). Los que tienen y los que no tienen, Alianza, Madrid, España. 
Mittelman, James H., (2002). El síndrome de la globalización, Siglo XXI, México.

Montalvo Ortega, Enrique, (2013). El neoliberalismo, la dictadura realmente perfecta, Paidós, INAH.

Munck, Ronaldo, (2005). Globalization and social exclusion. Bloomfield, New York.

O’Connor, James, (2001). Causas naturales, ensayos de marxismo ecológico, Siglo XXI, México.

Oxfam, México (2015). Desigualdad extrema en México, in https://www.oxfammexico.org/sites/default/ files/desigualdadextrema_informe.pdf, consultado en 20 de Octubre de 2019

Paris, Jean, (1954). Shakespeare, Édition du Seuil.

Poe, Edgar Allan, Un descenso al Maelström, http:// www.biblioteca.org.ar/libros/133646.pdf, consultado el 23 de noviembre de 2019.

Polanyi, Karl, (2011). La gran Transformación, los orígenes políticos y económicos de nuestro tiempo, $\mathrm{CFE}$, segunda reimpresión.

Rajan, Raghuram G, (2011). Grietas del sistema. Por qué la economía mundial sigue amenazada, Editorial, Deusto.

Rodrik, Dani, (2011). La paradoja de la globalización: la democracia y el futuro de la economía mundial. Editorial: Antonio Bosch: Barcelona, España.

Saxe-Fernández, John, (2014). “Migración forzada en México y diseño económico-' geopolítico de Posguerra”, en Ana María Aragonés, coordinadora, Crisis económica y migración, ¿Impactos temporales o estructurales?, México: UNAM, Instituto de Investigaciones Económicas.

Sen, Amartya, (1995). Nuevo examen de la desigualdad, Alianza editorial, Madrid, 1995.

Willamson, John, (1993). Democracy and the Washington Consensus, en World Development, vol. 21).

Zanfrini, Laura, (2007). La convivencia interétnica. Madrid: Alianza editorial.

Zizek, Slavoj, (2016). La nueva lucha de clases. Los refugiados y el terror, Anagrama, Barcelona, España.
'Término utilizado por Polanyi para explicar la acción desregulada del mercado en el capitalismo liberal y su lógica por acumular, engullir y devorar todo a su paso hasta el medio ambiente.

iiEstos términos son equivalentes para Karl Polanyi.

iiiEn términos de Polanyi, es cuando la economía se separa de la sociedad, no está al servicio de ésta y la subordina.

ivPoe Edgar Alan, Un descenso al Maelström, http://www.biblioteca.org.ar/libros/133646.pdf 